\title{
Essay (Cyberspeech)
}

\section{We Have a Dream: A Call to All Men and Women of Science and Religion to Rise Up}

\author{
Huping $\mathrm{Hu}$ \\ Dated: February 18, 2008
}

\begin{abstract}
In the spirit of Thomas Jefferson, Abraham Lincoln and Martin Luther King, Jr., we call all men and women of Science and Religion to rise up in the pursuit of truth.
\end{abstract}

Key Words: science, religion, truth, freedom, equality, honesty, tolerance

\section{Preamble}

Over the course of human history mankind brought forth on this planet, two chief systems for exploring Nature and Life, one of them is Religion and the other Science, both conceived for seeking truths, and both dedicated to the survival and advancement of mankind.

We hold these truth to be both spiritually and scientifically approachable that all forms of existence are interconnected, that they possess certain fundamental and unalienable properties - that to describe this interconnectedness and these properties, successive theories shall be constructed by us, deriving their explanatory and predictive powers from the approximations of laws of Nature and Life - that whenever any theory becomes inadequate of these ends, it is our duties to modify it or to abolish it, and to establish new ones, laying the foundation on such principles and organizing the structures in such forms, as to us shall seem most likely to reflect our understanding and knowledge of Nature and Life.

\section{The Ongoing Struggle}

We are now engaged in a great war over and within Science and Religion, testing whether they so conceived and so dedicated can be reconciled and advanced. We are also engaged in a silent struggle in Science, testing whether our yearning for truth and our love for mankind can conquer our own shortcomings - close-mindedness, arrogance, hypocrisy, selfishness, rivalry, comercialism and intolerance of alternative views.

\section{Call for Reflection}

So, on this day and in this era, it is appropriate that we - scientists, theologians, all other learned scholars - both formally educated and self-learned - and indeed all

Corresponding author: Huping Hu, Ph.D., J.D.,

Address: Biophysics Consulting Group, 25 Lubber Street, Stony Brook, NY 11790, USA.

E-mail: hupinghu@quantumbrain.org 
who love truth and mankind - reflect on the status of Science and Religion and our own moralities and conducts with the great hope of advancing and unifying both so as to better serve the needs and desires of mankind in the new millennium and bring the same into a new era of unprecedented enlightenment and progress.

\section{The Religious Age}

Before the advent of Science, various types of Religion were the main sources of knowledge guiding mankind in their struggles of survival and understanding of Nature and Life. And some would say that for a long stretch of time in history mankind was in a dark age.

\section{Scientific Revolutions}

Five hundred years ago, a great polymath, jurist and astronomer Copernicus on whose and other giants' shoulders we stand today, started the scientific revolution. His momentous work, On the Revolutions of the Celestial Spheres, came as a great beacon light to Kepler, Galileo, Newton, Maxwell and others who continued and completed the scientific revolution. It came as a joyous daybreak to end the long night of the dark age. However, these great men themselves were all deeply religious. What they had helped mankind to free from was not religious faiths which we all are entitled to have as precious as liberty and as vital as air but erroneous religious dogmas.

One hundred fifty years ago, a great naturalist Darwin and a great priest and scientist Mendel on whose paths modern biologists continue their work today, started the modern revolution in biological sciences. Their respective monumental work, On the Origin of Species and Experiments on Plant Hybridization, came as great guiding principles to modern biologists including Watson and Crick and countless others who continued and completed the revolution in biology. Darwin's work also created an earthquake in Religion greatly shaking the already weakened ties between Science and Religion.

One hundred years ago, a great physicist Planck and another great physicist and Swiss patent clerk Einstein on whose shadow modern physicists stand today, started the modern revolution in physics. Einstein's momentous work, Special Theory of Relativity, came as a shocking reckoning that there seems no place for spirituality in the universe. At the same time, Planck and Einstein's respective monumental work on the quanta came as a great jumping board for the quantum leap of Bohr, Schrodinger, Heisenberg, Dirac and many others who continued and completed the quantum theory of the modern revolution in physics which seemed to revive spirituality as chance, chaos and probability.

\section{Aftermath of the Revolutions}

No doubt that Science has brought mankind unprecedented material wealth and prosperity. Yet, the very wealth and prosperity have displaced spirituality from many among us. The very revolutions have created a deep gulf between Science and Region as reflected by increased hostilities and seemingly irreconcilable differences between Science and Religion. The very same revolutions have also produced dogmas, arrogance and intolerance of alternative views in Science. On the other hand, it may be said that the enterprises of Religion seem to lack innovations and are unable to cope with or adapt to the new environments.

Thus, after all these revolutions, the modern 
human is not spiritually enlightened or free. After all the revolutions, the spiritual lives of many among us are sadly crippled by the manacles of mechanical view and the prisons of random chance and chaos. After all the revolutions, we live on a lonely island of stale spirituality in the midst of a vast ocean of material wealth. After all the revolutions, many among us are languishing in the corners of alternative sciences and find themselves scientifically in exiles on their own planet. Indeed, after all the revolutions, the moralities of many among us are degenerating, many among us become selfish, mean-spirited, non-collaborative and too commercial, and some among us even become hypocritical, untruthful and are driven by money, power and fame. So today we dramatize these depressing and shameful conditions.

\section{A Promissory Note}

In a sense, all men and women of Science and Religion need now make a promissory note to mankind. A note promises that all of us in Science and Religion shall rise above ourselves and shall work and struggle together for the survival and advancement of mankind, and that all truth-seeking men and women shall be guaranteed the rights of freedom, equality and opportunity to be heard in the pursuit of truth.

It may be said that today some among us in Science and Religion would have defaulted on this promissory note if made earlier. Instead of honoring these obligations, some among us would have given mankind a bad check, a check which would have come back marked "insufficient funds." But we refuse to believe that the banks of Science and Religion would be bankrupt. We refuse to believe that there would be insufficient funds in the great vaults of Science and Religion.
So all of us in Science and Religion should make good on the promissory note - a note that will in the long run give mankind the riches of knowledge and the security of truth.

\section{Fierce Urgency}

Let us remind ourselves the fierce urgency of now. This is no time to engage in the luxury of silence or to take the tranquilizing drug of innocence. Now is the time to make real progress in Science and Religion. Now is the time to rise from the dark and desolate valley of mechanical and spiritless material world to the sunlit path of living universe. Now is the time to lift Science and Religion from the quick sands of arrogance, close mindedness, intolerance and hypocrisy to the solid rock of glorious path to truth. Now is the time to make freedom, equality and opportunity to be heard a reality for all truth-seeking men and women.

\section{Warning}

It would be fatal for the establishments of Science and Religion to overlook the urgency of the moment. This sweltering heat of many truth-seeking men and women's discontents will not pass until there is an invigorating atmosphere of freedom, equality and opportunity to be heard in Science and Religion. This is not an end, but a beginning. Those who hope that we needed to blow off steam and will soon be content will have a rude awakening if the establishments of Science and Religion return to their businesses as usual. There will be neither rest nor tranquility in Science and Religion until all truth-seeking men and women are granted their rights. The whirlwinds of revolt will come to shake the establishments of Science and Religion until the bright day of freedom, equality and opportunity to be heard emerges. 


\section{Precaution}

There is something else that we must say to all truth-seeking men and women who stand on the warm threshold which leads into the glorious path to truth. In the process of gaining our rightful place we must not be guilty of wrongful deeds. Let us not seek to satisfy our thirst for freedom, equality and opportunity to be heard in the pursuit of truth by drinking from the cup of bitterness and hatred.

We must forever conduct our struggle on the high plane of dignity and discipline. We must not allow our creative protest to degenerate into personal attacks or worse. Again and again we must rise to the majestic heights of meeting negative forces with positive forces. The marvelous new rebel which shall engulf the establishments of Science and Religion must not lead us to a distrust of all scientists, theologians and priests in the establishments, for many of them, as evidenced by their silence, have come to realize that their destiny is tied up with our destiny. They have come to realize that their yearning for freedom, equality and opportunity to be heard is inextricably bound to ours. We cannot walk alone.

At this critical moment, we must also ask ourselves the soul searching question: Are we really for truth and the greater benefit of mankind or our self-interests? And do we want to go down in history as hypocrites or truth-seeking men and women? And so, as John F. Kennedy would urge: My fellow seekers of truth: ask not what mankind can do for you but what can you do for mankind.

\section{Demand}

As we walk, we must make the pledge that we shall always march ahead. We cannot turn back. There are those who ask, "When will you be satisfied?" We can never be satisfied as long as mankind is short-changed by hypocrisy and repression in the establishments of Science and Religion. We can never be satisfied, as long as our intellectual properties, cultivated and harvested with sweat, cannot gain entries into the journals and electronic archives of Science and Region guarded by the establishments. We can never be satisfied as long as young generations of men and women are stripped of their inquiring minds and robbed of their intellectual freedom by signs stating "Establishment Science Only." We cannot be satisfied as long as a scientist outside the establishment cannot get his paper published in a peer-reviewed journal and a scientist in the establishment believes he has nothing for which to write. No, no, we are not satisfied, and we will not be satisfied until freedom and equality roll down like waters and opportunity to be heard like a mighty stream.

\section{Creative Suffering}

We are not unmindful that some among us have suffered great trials and tribulations. Some among us are still in the suffocating environment of suppression. Some among us have just left from areas where their quest for truth left them battered by the storms of persecution and staggered by the winds of establishment tactics. Some among us have been the veterans of creative suffering. Continue to work with the faith that unearned suffering is redemptive.

Go back to your work, go back to your study, go back to your laboratory, go back to your seminary, go back to your place of worship, go back to the backwaters of alternative science, go back to the forgotten paths of spirituality knowing that somehow this 
situation can and will be changed. Let us not wallow in the valley of despair.

\section{We have a Dream}

We say to you today, fellow scientists, priests, theologians and all truth-seeking men and women, so even though we face the difficulties of today and tomorrow, we still have a dream in the spirit of Martin Luther King, Jr. It is a dream deeply rooted in the pursuit of truth and the struggle for the survival and advancement of mankind. Let us remember that neither Science nor Religion is above truth.

We have a dream that one day the sacred enterprises of Science and Religion will rise up and live out the true meaning of their creed: spirit of collaboration, cooperation, honesty and tolerance in the pursuit of truth; and freedom, equality and opportunity to be heard for all truth-seeking men and women.

We have a dream that one day in the halls of Science and the towers of Religion scientists, priests and the theologians will be able to sit down together at the table of truth-hood.

We have a dream that one day even a fundamentalist church, sweltering with the heat of religious zeal, sweltering with the heat of anti-science, will be transformed into an oasis pursuing truth.

We have a dream that young generations will one day study in institutions where they will not only learned established sciences but also exposed to alternative scientific views and be judged not by their particular views but by the content of their character.
We have a dream today.

We have a dream that one day, all truthseekers, men or women, will be treated equally by every institute - university, college, church, seminary or school - on every corner of Earth.

We have a dream today.

We have a dream as that of Martin Luther King, Jr. "that one day every valley shall be exalted, every hill and mountain shall be made low, the rough places will be made plain, and the crooked places will be made straight, and the [truth] shall be revealed, and all flesh shall see it together."

This is our hope. This is the faith that we go on in the pursuit of truth. With this faith as that of Martin Luther King, Jr. "we will be able to hew out of the mountain of despair a stone of hope. With this faith we will be able to transform the jangling discords of [Science and Religion] into a beautiful symphony of [truth-hood and scholar -hood]." With this faith we will be able to study together, to work together, to struggle together, to pray together, to stand up for truth and knowledge together, knowing that we will be truly free one day.

This will be the day when everyone will be able to sing as Rumi "I am so tipsy here in this world, I have no tale to tell but tipsiness and rapture."

\section{Let Freedom and Knowledge Ring}

And if Science and Religion are sacred enterprises of truth this must become true. So let freedom and knowledge ring from the prestigious colleges of Harvard. Let freedom and knowledge ring from the mighty ivory 
campuses of Yale. Let freedom and knowledge ring from the advanced institutes of Princeton!

Let freedom and knowledge ring from the academic institutes of America!

Let freedom and knowledge ring from the academic institutes of Europe!

Let freedom and knowledge ring from the academic institutes of Asia!

Let freedom and knowledge ring from the academic institutes of Africa!

Let freedom and knowledge ring from the academic institutes of every nation!

Let freedom and knowledge ring from the journals of Science!

But not only that; let freedom and knowledge ring from the journals of Religion!

Let freedom and knowledge ring from every religious institutions of every nation. From every corner of Earth, let freedom and knowledge ring.

And when this happens, when we allow freedom and knowledge to ring, when we let them ring from every university, every school and every church, from every state and every country, we will be able to speed up that day when Religion and Science of mankind, by mankind, for mankind shall be unified and united.

\section{Tribute and Resolve}

And let us now pay tribute to those who have greatly contributed towards the advancement and reconciliation of Science and Religion. But, as Abraham Lincoln would declare, in a larger sense we cannot compose anything proper to honor those heroes. The brave men and women, living and dead, who struggled, have already done so, far above one's poor power to add or detract. The world may be little notice what we say here, but it can never forget what they have done. It is for rest of us, rather, to be dedicated here to the unfinished work which they who fought have thus far so nobly advanced. It is rather for us to be here dedicated to the great task remaining before us, that from these honored we take increased devotion to the cause for which they have given their full measure of devotion, that we here highly resolve that these dedicated shall not have fought in vain, that Science and Religion of mankind, by mankind, for mankind shall have a new birth, and that mankind shall advance and shall not perish from the earth.

Acknowledgement: The layout of this Essay (Cyberspeech) "We Have a Dream" is based on Martin Luther King. Jr.'s speech known as "I Have a Dream." The Essay is also fused with languages from the Declaration of Independence the chief drafter of which was Thomas Jefferson and Abraham Lincoln's Gettysburg Address. It also contains a modified quote from John F. Kennedy. 